\title{
Craniocervical posture analysis in patients with temporomandibular disorder
}

\author{
Análise da postura cranio-cervical em pacientes com disfunção \\ temporomandibular
}

lunes DH', Carvalho LCF², Oliveira AS³, Bevilaqua-Grossi D³

\begin{abstract}
Objective: To compare head positioning and cervical spine alignment between individuals with and without temporomandibular disorders (TMDs), by means of positional evaluation using photographs, radiographs and visual observation, and to investigate whether the type of TMD influences head posture and cervical spine positioning. Methods: Ninety randomly chosen women were diagnosed using the research diagnostic criteria for TMDs (RDC/TMD) by a trained examiner and were divided into three groups: Group 1, with a diagnosis of myofascial dysfunction (group I of RDC axis I); Group 2, with mixed TMD (groups I, II and III of RDC axis I); and Control, without TMD. Following this, the participants were photographed in frontal and lateral views by a single examiner. To produce these photos, the following anatomical points were marked out on the skin: occipital protuberance, C4, C7, acromioclavicular joint and sternoclavicular joint. From these points, different angles were analyzed by means of the ALCimagem-2000 application. These same photos were then evaluated qualitatively (visual evaluation). Next, lateral teleradiography and radiography of the cervical spine was requested. The examiner was blind when analyzing the images. To compare the results, the chi-squared test and analysis of variance were used, with significance levels of $5 \%$. Results: Regardless of the method used, the results revealed that head and cervical spine posture did not differ between the groups with and without TMD, independent of the diagnostic group. Conclusion: The posture of individuals with myogenic or arthrogenous TMD does not differ from the posture of individuals without TMD. The presence of TMD does not influence the head and cervical spine posture.
\end{abstract}

Key words: temporomandibular joint; photogrammetry; cephalometry; posture.

\section{Resumo}

Objetivo: Comparar o posicionamento da cabeça e o alinhamento da coluna cervical em indivíduos com e sem DTM, por meio da avaliação postural por fotografias, radiografias e por observação visual e verificar se o tipo de DTM influencia na postura da cabeça e no posicionamento da coluna cervical. Métodos: Noventa mulheres escolhidas aleatoriamente foram diagnosticadas por meio dos Critérios para Diagnóstico em Pesquisa para Disfunções Temporomandibulares (RDC/TMD) por um examinador treinado e divididas em três grupos: grupo 1, diagnóstico de disfunção miofascial (grupo I do eixo I do RDC); grupo 2, com DTM mista (grupo I, II e III do eixo I do RDC) e controle, sem DTM . Em seguida, foram fotografadas em vista anterior e em perfil por um único examinador. Para a realização dessas fotografias, foram demarcados sobre a pele os seguintes pontos anatômicos: protuberância occiptal, C4, C7, articulação acromioclavicular e esternoclavicular. A partir desses pontos, foram analisados diferentes ângulos por meio do aplicativo ALCimagem2000. Essas mesmas fotos foram posteriormente avaliadas qualitativamente (avaliação visual). Em seguida, foi solicitada uma radiografia e uma telerradiografia em perfil. O examinador foi cego ao analisar as imagens. Para comparação dos resultados, foi utilizado o teste quiquadrado e a análise de variância com nível de significância de 5\%. Resultados: Independentemente do método utilizado, os resultados revelaram que a postura da cabeça e da coluna cervical não diferem entre o grupo com DTM e sem DTM, independentemente do grupo diagnosticado. Conclusão: A postura do indivíduo com DTM miogênica ou artrogênica não é diferente do indivíduo sem DTM. A presença da DTM não influencia na postura da cabeça e da coluna cervical.

Palavras-chave: articulação temporomandibular; fotogrametria; cefalometria; postura.

Received: 08/07/2008 - Revised: 26/09/2008 - Accepted: 11/11/2008

${ }^{1}$ Physical therapy course, Universidade Federal de Alfenas (UNIFAL), Alfenas (MG), Brazil

2Dentistry course, UNIFENAS

${ }^{3}$ Physical therapy course, Universidade de São Paulo (USP), Ribeirão Preto (SP), Brazil

Correspondence to: Denise Hollanda lunes, Rua Prof. Carvalho Junior, 53 - Apto 901, CEP 37130-000, Alfenas (MG), e-mail: deniseiunes@yahoo.com.br 


\section{Introduction $: \therefore$.}

Musculoskeletal structural disorders of the masticatory system are frequent: $50 \%$ to $75 \%$ of the population presents at least one sign of temporomandibular disorder (TMD) and among these, $25 \%$ present symptoms of this disorder ${ }^{1}$. The most important characteristic of such dysfunctions is chronic pain $^{1-3}$. Because of its high prevalence, TMD has been considered to be a public health condition and has become a subject of interest among professionals and researchers ${ }^{4}$.

TMD is a multifactorial syndrome ${ }^{5-8}$. The etiological factors include mandibular structural abnormalities, neuromuscular abnormalities $^{5,6,9}$ and stress ${ }^{5,9}$. Many authors have claimed that patients with TMD present head and neck postural abnormalities ${ }^{5,10,11}$.

The association between TMD and head, neck and mandibular postures has been widely researched and discussed for years and has given rise to divergences. Some authors have claimed that patients with TMD present postural abnormalities of head and neck lordosis more frequently than patients without $\mathrm{TMD}^{5,10-16}$. However, other authors ${ }^{2,8,17}$ have claimed that individuals with TMD present no more abnormalities in these segments than individuals without TMD. Despite the controversy, most studies have included patients with signs and symptoms of TMD. In none of these studies were the patients selected by means of an index for TMD diagnostic reliability and validity, such as the research diagnostic criteria for TMDs $(\mathrm{RDC} / \mathrm{TMD})^{18}$, which are considered to be the gold standard for $\mathrm{TMD}^{19}$ diagnosis having been accepted and validated in several languages ${ }^{20}$.

Therefore, the objective of the present study was to compare head position and cervical spine alignment among individuals, with and without TMD, selected by means of the RDC/ $\mathrm{TMD}^{18}$. Postural evaluation and quantitative postural analysis techniques such as photogrammetry and radiography were used in this analysis.

\section{Methods : : :}

\section{Sample}

Ninety randomly chosen female participants were analyzed using a TMD severity classification questionnaire the Fonseca ${ }^{21}$ and the $\mathrm{RDC} / \mathrm{TMD}^{18}$. They were divided into three groups: Control group, formed by 30 asymptomatic individuals of mean age $26.17 \pm 9.18$ years, mean weight $57.77 \pm 9.69 \mathrm{~kg}$ and mean height $1.63 \pm 0.07 \mathrm{~m}$; they were included if they did not present signs and symptoms of TMD according to RDC/TMD ${ }^{5}$; Group 1, formed by 30 individuals presenting muscle signs and symptoms of TMD (group 1 of RDC axis I, of which $86.67 \%$ were la and $13.33 \%, 1 b$ ), of mean age $29.13 \pm 11.45$ years, mean mass $60.10 \pm 7.99 \mathrm{~kg}$ and mean height $1.61 \pm 0.06 \mathrm{~m}$; Group 2, formed by 30 individuals presenting muscle signs and symptoms of TMD such as established diagnoses of dislocation and joint disorders (groups I, II and III of RDC axis I). In Group 2, 100\% had myofascial pain, $80 \%$ disc displacement and $33.3 \%$ arthralgia and osteoarthritis, with mean age $28.13 \pm 9.42$ years, mean weight $58.83 \pm 7.99 \mathrm{~kg}$ and mean height $1.61 \pm 0.07 \mathrm{~m}$. Individuals rated moderate and severe according to the Fonseca anamnesis index ${ }^{18}$ were included in groups 1 and 2, respectively.

All of the participants were initially contacted by phone or in person. The exclusion criteria for all groups were neurological problems, rheumatic diseases, physical deficiency, previous mandibular fracture, previous orthogenetic surgery and current use of dental prostheses ${ }^{2}$. For the control group, the presence of TMD diagnosis was an additional exclusion criterion. They all received information about their potential participation in the project and signed a statement in which they agreed to participate in the research, in accordance with Resolution 196/96 of the National Health Council. The experimental protocol for this study was approved by the Human Research Ethics Committee of Universidade José do Rosário Vellano-UNIFENAS (number 78/2005)

In total, 116 individuals were evaluated, but only 90 met the inclusion and exclusion criteria and therefore 90 individuals took part in the study.

\section{TMD evaluation}

The participants were seated with their arms and back supported and underwent a clinical examination in accordance with RDC/TMD axis $\mathrm{I}^{18}$. Following this, the Fonseca anamnesis index was applied ${ }^{21}$.

\section{Photographic record}

Photographs were taken of the face in the frontal plane and of the whole body in the sagittal plan, with the evaluated structures marked out. Two digital cameras were used: one to photograph the frontal plane and the other for the sagittal plane (SONY ${ }^{\circledR}$ Cybershot, 5.1 megapixels resolution, and $S O N Y^{\circledR}$ Cybershot, 7.2 megapixels resolution), positioned parallel to the floor and each mounted on a leveled tripod. The room was well lit with a non-reflective background, and the area was secluded thus enabling individual privacy while the photographs were taken. The digital images obtained were 2048 x 1536 pixels in size and were stored for future analysis. The skin markings were always positioned by the same experienced investigator, who also took all the photographs. 


\section{Participant positioning}

For the photographs, the participants stood upright, positioned at a previously marked place, at a standard distance from the camera, which was also at a previously marked spot. The camera was $2.4 \mathrm{~m}$ from the participant, on a tripod at a height of $1.0 \mathrm{~m}$ from the floor, in order to photograph the whole body. The pictures of the face were taken with a camera $94 \mathrm{~cm}$ from the participant, on a tripod $1.53 \mathrm{~m}$ from the floor. This distance made it possible to frame the participant's head from the top to the base of the clavicle ${ }^{22}$.

\section{Marked points}

The following anatomical points were bilaterally marked on the participants' body to serve as reference points for the evaluated angles: sternoclavicular joints; acromioclavicular joints; occipital protuberance; $\mathrm{C}_{4}$ spinous process; and $\mathrm{C}_{7}$ spinous process. Another five points that were analyzed (relating to the external orbicular angle, labial commissure and center of ear tragus) did not need markings because they can be easily seen. The markings were made using the resources and procedures described by Iunes et al. ${ }^{22}$

\section{Analyzed angles}

The digital photographs were analyzed using the ALCimagem-2000 software, version 1.5. This made it possible to digitally draw the straight lines that determine the angular values in degrees for corresponding reference points asymmetrically positioned on the left and right dimers of the body. The reliability of this procedure had previously been tested ${ }^{22}$. The following angles described by Iunes et al..$^{22}$ were drawn in the frontal plane: external orbicular (EO); labial commissure (LC); acromioclavicular joint (AC) and sternoclavicular joint (SC). In the sagittal plane, the following were analyzed: head protrusion (HP) and cervical lordosis (CL). These angles were only analyzed after all of the participants had been evaluated and all the radiographs had been taken. The investigator who performed the analyses was blind with regard to the group. For each analysis, the investigator took three consecutive measurements, and the value for each analyzed angle was the arithmetic mean of these three measurements.

\section{Radiography}

Two radiographs were requested for each participant: one of the cervical spine, taken laterally to analyze cervical lordosis, and one lateral cephalometric teleradiograph to analyze occipital positioning, i.e. the relationship between cervical and hyoid bone positioning. All of the radiographs were taken by the same professional. The Ortholax $S D$ Ceth x-ray device (Philips) was used, with T MAT G Kodak 24x30cm radiographic film. The distance between the X-ray device and the film was $1.52 \mathrm{~cm}$. The film was processed in an automatic processor. The participant was positioned standing laterally to the X-ray device with the body relaxed and the feet $10 \mathrm{~cm}$ apart, over a marked point on the floor corresponding to the cephalostatic center. The arms were positioned along the body and a $1.0 \mathrm{~kg}$ bar was held in each hand in order to force the shoulders down and allow better viewing of the cervical spine. The participant was asked to direct his gaze horizontally and take a deep breath followed by smooth expiration and then his normal breathing pattern. Following this, the olives were positioned by touching the participant's face (not necessarily in the hearing channel), in order to stabilize the head laterally, while preserving the natural positioning of the head ${ }^{23}$.

\section{Radiographic analysis}

The measurements were made using a correlometer and always by the same professional. Thus, like the photos, the cephalograms were numbered and shuffled so that the examiner was blind for this analysis.

\section{Cephalometric analysis}

This analysis was done by measuring the occipital-atlas (O-A) distance, craniovertebral angle, hyoid ( $\left.\mathrm{H}-\mathrm{H}^{\prime}\right)$ distance, cervical lordosis as described by Rocabado ${ }^{24}$ and cervical gravitational angle as described by Deltoff ${ }^{25}$.

The O-A distance is a linear measurement from the base of the occipital (point $\mathrm{O}$ ) to the posterior arch of the atlas (point $\mathrm{A})^{24}$. The $\mathrm{H}-\mathrm{H}^{\prime}$ distance is a linear measurement between the most anterosuperior point of the hyoid bone $(\mathrm{H})$ and the $\mathrm{H}^{\prime}$ line, which is a line between the most anteroinferior point of $\mathrm{C} 3$ and the most posteroinferior point of the mental symphysis ${ }^{24}$.

\section{Visual evaluation}

The cervical lordosis was classified as normal, rectified or hyper-lordosis and the head was classified as protruded or normal ${ }^{26}$.

\section{Statistical analysis}

For analyses that involved two qualitative variables, the chi-squared test was used. For analyses involving two variables in which one of them was qualitative, analysis of variance was used: this consisted of determining whether the 
average values for the different groups were different or the same. When there were more than two groups to be compared, analyses among the groups were done based on the Tukey test. When there were two groups to be compared, the analysis was done based on the t test. In all the analyses, the significance level was 0.05 .

\section{Results : :}

Ten X-rays were set aside and two other examiners analyzed them in order to test the inter-examiner reliability of the measurements made. One of these examiners made the same measurements on two different occasions (intra-examiner reliability). The results from the intraclass correlation coefficient (ICC) demonstrated that the reliability for all analyzed measurements was excellent, except for one analysis $\left(\mathrm{H}-\mathrm{H}^{\prime}\right.$ distance) with moderated reliability, as shown in Table 1.

Photogrammetry analysis: It was observed that all the segments presented similar mean angles, independent of TMD type or lack of TMD (Table 2).

Table 1. Intraclass correlation coefficient (ICC) for intra and interexaminer reliability of the radiographic analyses by Rocabado ${ }^{24}$ (craniovertebral angle, 0-A distance and hyoid triangle) and the analyses by Deltoff. ${ }^{25}$ (cervical Iordosis, deep lordosis and cervical gravitation line). $\mathrm{N}=10$.

\begin{tabular}{lcc}
\hline ANGLES & ICC INTER & ICC INTRA \\
\hline Craniovertebral angle & 0.88 & 0.86 \\
\hline $0-\mathrm{A}$ & 0.96 & 0.95 \\
\hline $\mathrm{H}-\mathrm{H}^{\prime}$ distance & 0.89 & 0.76 \\
\hline Cervical angle curve & 0.86 & 0.92 \\
\hline Gravitational cervical line & 0.96 & 0.98 \\
\hline Cervical depth & 0.99 & 0.93 \\
\hline
\end{tabular}
$p>0.05$.

Table 2. Mean and standard EO (external orbicular) angle deviation, LC (labial commissure), AC (acromioclavicular), SC sternoclavicular, HP (head protrusion) and CL (cervical lordosis) observed by means of photogrammetry for the three groups, without control (individuals without TMD), group 1 (myogenic TMD) and group 2 (mixed TMD).

\begin{tabular}{lcccc}
\hline Angle & Group 1 $(n=30)$ & Group 2 $(n=30)$ & Control $(n=30)$ & $p$ \\
\hline EO & $-0.50 \pm 2.61$ & $-0.90 \pm 3.37$ & $-0.75 \pm 2.61$ & 0.86 \\
\hline LC & $-0.99 \pm 2.17$ & $-0.77 \pm 3.55$ & $-0.39 \pm 2.57$ & 0.64 \\
\hline AC & $-0.02 \pm 2.25$ & $0.00 \pm 2.58$ & $1.13 \pm 2.13$ & 0.10 \\
\hline SC & $0.66 \pm 4.36$ & $0.35 \pm 4.29$ & $0.67 \pm 3.76$ & 0.95 \\
\hline HP & $51.5 \pm 5.35$ & $49.2 \pm 5.27$ & $50.9 \pm 5.21$ & 0.21 \\
\hline CL & $34.3 \pm 7.98$ & $33.2 \pm 14.02$ & $35.5 \pm 7.82$ & 0.69 \\
\hline
\end{tabular}

$\mathrm{p}<0.05$; statically different.
Radiography analysis: None of the cervical curve or head position measurements presented any differences between the groups (Table 3).

Visual analysis: There were no differences among the three groups regarding head positioning (Table 4) or cervical lordosis (Table 5).

\section{Discussion $: \because$.}

The data from this study raise questions regarding other studies that claimed that individuals with TMD presented more abnormalities of head and cervical positioning than individuals without TMD. In the present study, abnormalities in head positioning and cervical spine alignment were found both in individuals with TMD and in individuals without TMD.

As stated earlier, we used the RDC/TMD system of Nilsson, List \& Drangsholt ${ }^{19}$ as a gold-standard operating system for TMD diagnosis, thus enabling better definition of the samples of individuals with and without TMD, so as to distinguish the

Table 3. Radiographic analysis comparing the cervical angles, cervical depth and gravitational cervical line as described by Deltoff ${ }^{25}$, and the cervical Iordosis, 0-A distance, craniovertebral angle and $\mathrm{H}$-H' distance, as described by Rocabado ${ }^{24}$. Cervical lordosis is a qualitative measurement.

\begin{tabular}{lcccc}
\hline Analyses & $\begin{array}{c}\text { Group 1 } \\
(n=30)\end{array}$ & $\begin{array}{c}\text { Group 2 } \\
(n=30)\end{array}$ & $\begin{array}{c}\text { Control } \\
(n=30)\end{array}$ & $p$ \\
\hline $\begin{array}{l}\text { Cervical angle } \\
\text { curve }\end{array}$ & $32.00 \pm 5.66$ & $33.57 \pm 10.56$ & $33.70 \pm 10.71$ & 0.50 \\
\hline $\begin{array}{l}\text { Cervical depth } \\
\text { Rocabado } \\
\text { cervical lordosis }\end{array}$ & $3.79 \pm 3.40$ & $4.57 \pm 5.30$ & $2.00 \pm 4.04$ & 0.69 \\
\hline $\begin{array}{l}\text { Gravitational } \\
\text { cervical line }\end{array}$ & $6.23 \pm 9.56$ & $1.23 \pm 9.07$ & $2.27 \pm 11.17$ & 0.10 \\
\hline O-A distance & $9.60 \pm 3.64$ & $8.93 \pm 2.67$ & $9.47 \pm 2.43$ & 0.68 \\
\hline $\begin{array}{l}\text { Craniovertebral } \\
\text { angle }\end{array}$ & $99.63^{\circ} \pm 8.03^{\circ}$ & $100.93^{\circ} \pm 7.09^{\circ}$ & $101.20^{\circ} \pm 7.58^{\circ}$ & 0.64 \\
\hline H- H' distance & $4.95 \pm 3.25$ & $3.47 \pm 2.86$ & $4.95 \pm 4.06$ & 0.18 \\
\hline
\end{tabular}

$\mathrm{p}<0.05$; statistically different.

Table 4. Head positioning, compared by visual analysis.

\begin{tabular}{lccc}
\hline Head Position & Group 1 $(n=30)$ & Group 2 $(n=30)$ & Control $(n=30)$ \\
\hline Protruded & $86.67 \%(n=26)$ & $80.00 \%(n=24)$ & $83.33 \%(n=25)$ \\
\hline Normal & $13.33 \%(n=4)$ & $20.00 \%(n=6)$ & $16.67 \%(n=5)$ \\
\hline
\end{tabular}
$\mathrm{p}<0.79$.

Table 5. Cervical lordosis, compared by visual analysis.

\begin{tabular}{lccc}
\hline Cervical Lordosis & Group 1 $(n=30)$ & Group 2 $(n=30)$ & Control $(n=30)$ \\
\hline Normal & $36.67 \%(n=11)$ & $50.00 \%(n=15)$ & $53.33 \%(n=16)$ \\
\hline Rectified & $60.00 \%(n=18)$ & $50.00 \%(n=15)$ & $46.67 \%(n=14)$ \\
\hline Hyperlordosis & $3.33 \%(n=1)$ & - & - \\
\hline
\end{tabular}
$p<0.44$. 
TMD types. Most of the studies in the literature using photos to analyze head positioning and quantify cervical lordosis evaluated individuals with TMD through their signs and symptoms ${ }^{2,7,10-12,14,27-29}$.

Among the studies in the literature using cephalometric tracing to compare head postures and cervical lordosis among patients with and without TMD, the evaluation was always based on signs and symptoms to select individuals with or without $\mathrm{TMD}^{2,9,13,15,30,31}$.

The same occurred with studies comparing the posture of individuals with or without TMD using visual evaluation ${ }^{5,6,16,17,32}$. Thus, there are no studies selecting participants by means of the RDC/TMD with which our results can be compared.

Despite the use of a different analysis method to evaluate eye symmetry (EO angle), Munhoz, Marques \& Siqueira ${ }^{8}$ and Shiau \& Chai $^{12}$ found results similar to ours, i.e. no differences in eye alignment between individuals with and without TMD. This differs from the findings of Zonnenberg et al. ${ }^{29}$, who observed that the group with TMD presented greater eye symmetry. This difference in results may be because the different authors gave different value to these parameters in their diagnoses of TMD.

With regard to mouth symmetry analysis data (LC), our results were similar to those of Shiau \& $\mathrm{Chai}^{12}$, who also found no differences in alignment in this region between individuals with and without TMD.

Like Munhoz, Marquez \& Siqueira ${ }^{8}$, we did not find any alignment differences in AC angles in the shoulders. However, some authors found greater asymmetry between the shoulders among individuals with $\mathrm{TMD}^{11,29}$.

We evaluated head position in the sagittal plane according to HP angle, using photogrammetry, and did not find any angular difference between individuals with and without dysfunction, thus agreeing with the results of Visscher et al. ${ }^{2}$, Ciacanglini et al. ${ }^{7}$, Munhoz, Marques \& Siqueira ${ }^{8}$ and Hackney, Bade \& Claw$\operatorname{son}^{28}$. However, other studies found that individuals with TMD presented greater head protrusion and therefore lower values for this angle. Although the HP angle presents good reliability, the differences can be ascribed to methodological differences between studies, as described earlier.

No differences in alignment regarding shoulder symmetry were found, as evaluated using the CA angle, as also seen by Munhoz, Marques \& Siqueira ${ }^{8}$. However, some authors found greater asymmetry of the shoulders among individuals with $\mathrm{TMD}^{11,29}$.

Concerning CL angles, even though some studies used a different evaluation of this region, no differences between the groups with and without TMD were found ${ }^{8,14}$.

The results relating to occipital-atlas $(\mathrm{O}-\mathrm{A})$ distance and craniovertebral angle revealed that there were no differences in these measurement between individuals with and without TMD, thus agreeing with Rocabado \& Tapia $^{30}$ and Matheus ${ }^{31}$.

Sonnesen, Bakke \& Solow $^{9}$ and Huggare \& Raustia ${ }^{13}$ used another cephalometric tracing method, which was described as NSL/OPT. This consisted of the angle between the nasion-sella line and the dorsal tangent to the odontoid process of the second cervical vertebra, in order to investigate the rotation of the cranium and find whether there was greater posterior rotation of the head. Therefore, according to those authors, individuals with TMD presented higher frequency of head extension or high cervical hyperlordosis compared to the individuals without TMD. Even though this was a common alignment observed in patients with TMD in the present study, the present data do not support those authors' results. In the same way, Visscher et $\mathrm{al}^{2}{ }^{2}$ did not observe any postural differences between their control group with TMD and different types of TMD.

Concerning cervical lordosis measured by radiography, the results from the present study showed that there were no differences in cervical alignment between individuals with and without TMD. This result was found using three measurements for lordosis: cervical curve angle, cervical depth and Rocabado's cervical lordosis ${ }^{24}$.

There are few studies in the literature qualitatively evaluating cervical lordosis through cephalometric alignments relating to $\mathrm{TMD}^{13,15,31}$. Huggare \& Raustia ${ }^{13}$ used a cervical lordosis measurement called the OPT/CVT angle, between the dorsal tangent to the odontoid process of the second cervical vertebra and the tangential line to the dorsal margins of the corpus of the third and fourth cervical vertebrae. D'Attilio et al. ${ }^{15}$ described another angle called the CVT/EVT, between the tangential line to the dorsal margins of the corpus of the third and fourth cervical vertebrae and the line through the most posteroinferior point in the corpus of $\mathrm{C}_{4}$ and $\mathrm{C}_{6}$. In both studies, the group with TMD presented smaller angles, i.e. cervical rectification in comparison with the control group. The disagreement between the results may be due to the reference points used for tracings, which evaluated only the $\mathrm{C}_{3}$ and $\mathrm{C}_{4}$ positions. However, the presence of cervical rectification is a common clinical sign among patients with TMD. The data from the present study did not differ with regard to cervical column alignment in the control group. The presence of rectification among the control group individuals in the present study is increasingly observed among the population, independently of whether musculoskeletal dysfunctions might be present. This suggests that postural habits may predispose towards increased tonic activities of the prevertebral muscles. Future studies may elucidate the prevalence of this posture among the population.

Concerning the hyoid position, evaluated according to the H - H' distance, Rocabado \& Tapia $^{30}$ reported that patients with TMD presented a lower hyoid position (lower than $\mathrm{C}_{3}$ ) 
than in individuals without TMD. Our results disagree with theirs, because we found that the hyoid position was similar in the groups with and without TMD.

The other methods of measuring the neck (cervical curve angle, cervical depth and cervical gravity line) did not produce measurements differing from the control group. There are no studies in the literature with which these findings can be compared.

The head positioning and cervical spine alignment evaluated by visual postural evaluation agreed with Darlow, Pesco \& Greenberg $^{17}$, and also found no differences in the incidence of abnormalities in these segments between individuals with and without TMD.

The data from the present study disagrees with the findings of Kritsineli \& Shim ${ }^{32}$, who found greater incidence of head protrusion among 40 children with TMD, in comparison with a control group, and with the findings of Nikolakis et al. ${ }^{5}$, who found head positioning that was more anterior and greater shoulder asymmetries in the TMD group, in comparison with a control group. These differences may be because both of those studies used the anterior alignment between the shoulders and head as the reference point, even though head protrusion does not necessarily occur when the shoulders protrude.

\section{References}

1. Olivo SA, Bravo J, Magee DJ, Thie NM, Major PW, Flores-Mir C. The association between head and cervical posture and temporomandibular disorders: a systematic review. J Orofac Pain. 2006;20(1):9-23.

2. Visscher CM, De Boer W, Lobbezoo F, Habets LL, Naeije M. Is there a relationship between head posture and craniomandibular pain? J Oral Rehabil. 2002;29(11):1030-6.

3. Pereira Jr FJ, Favilla EE, Dworkin S, Huggins K. Critérios de diagnóstico para pesquisa das disfunções temporomandibulares (RDC/TMD) tradução oficial para a língua portuguesa. J Bras Clin Odontol Integr. 2004;8(47):384-95.

4. John MT, Dworkin SF, Mancl LA. Reliability of clinical temporomandibular disorder diagnoses. Pain. 2005;118(1):61-9.

5. Nicolakis P, Nicolakis M, Piehslinger E, Ebenbicheler G, Vachuda M, Kirtley $C$, et al. Relationship between craniomandibular disorders and poor posture. Cranio. 2000;18(2):106-12.

6. Pedroni CR, Oliveira AS, Guaratini Ml. Prevalence study of signs and symptoms of temporomandibular disorders in university students. J Oral Rehabil. 2003;30(3):283-9.

7. Ciancaglini R, Colombo-Bolla G, Gherlone EF, Radaelli G. Orientation of craniofacial planes and temporomandibular disorder in young adults with normal occlusion. J Oral Rehabil. 2003;30(9):878-86.

8. Munhoz WC, Marques AP, Siqueira JT. Evaluation of body posture in individuals with internal temporomandibular joint derangement. Cranio. 2005;23(4):269-77.
The three methods used to evaluate head positioning and cervical lordosis (photogrammetry, radiography and visual evaluation) showed the presence of postural abnormalities in the TMD group, but these abnormalities did not differ from those found in the group without TMD.

Despite the biomechanical relationships between ATM, cervical column and head position and the common presence of changes in these segments among individuals with TMD, the data from the present study do not support the hypothesis and suggest that posture should not be interpreted as an etiological factor predisposing TMD. Rather, the present data agree with the findings of Bevilaqua-Grossi, Chaves \& Oliveira ${ }^{33}$, i.e. that such findings can be interpreted as an independent factor.

\section{Conclusion $: \because$.}

The presence of TMD did not influence head and cervical posture, according to photographic, radiographic and visual analyses.

Different TMD classification types did not imply differences in head and cervical alignment.

9. Sonnesen L, Bakke M, Solow B. Temporomandibular disorders in relation to craniofacial dimensiones, head posture and bite force in children selected for orthodontic treatment. Eur J Orthod. 2001;23(2):179-92.

10. Lee WY, Okenson JP, Lindroth J. The relationship between forward head posture and temporomandibular disorders. J Orofac Pain. 1995;9(2):161-7.

11. Fuentes FR, Freesmeyer W, Henriquez PJ. Influencia de la postura corporal em la prevalência de lãs disfunciones craneomandibulares. Rev Med de Chile. 1999;127(9):1079-85.

12. Shiau YY, Chai HM. Body posture and hand strength of patients with temporomandibular disorders. Cranio. 1990;8(3):244-51.

13. Hugare JA, Raustia AM. Head posture and cervicovertebral and craniofacial morphology in patients with craniomandibular dysfunction. Cranio. 1992;10(3):173-9.

14. Yi LC, Guedes ZCF, Vieira MM. Relação da postura corporal com a disfunção da articulação temporomandibular: hiperatividade dos músculos da mastigação. Fisioter Bras. 2003;4(5):341-7.

15. D'Attilio M, Epifania E, Ciuffolo F, Salini V, Filippi MR, Dolci M, et al. Cervical lordosis angle measured on lateral cephalograms; findings in skeletal class II female subjects with and without TMD: a cross sectional study. Cranio. 2004:22(1):27-44.

16. Ferraz Junior AML, Guimares JP, Rodrigues MF, Lima RHM. Avaliação da prevalência das alterações posturais em pacientes com desordem 
temporomandibular: uma proposta terapêutica. Revista Serviço ATM. 2004;4(2):24-32.

17. Darlow LA, Pesco J, Greenberg MS. The relationship of posture to myofascial pain dysfunction syndrome. J Am Dent Assoc. 1987;114(1)73-5.

18. Dworkin SF, LeResche L. Research diagnostic criteria for temporomandibular disorders: review, criteria, examinations and specifications, critique. J Craniomandib Disord. 1992;6(4):301-55.

19. Nilsson IM, List T, Drangsholt M. The reliability and validity of selfreported temporomandibular disorder pain in adolescents. J Orofac Pain. 2006;20(2):38-44.

20. Kominsky M, Lucena LBS, de Siqueira JTT, Pereira Jr FJ, Góes PSA. Adaptação cultural do questionário research diagnostic criteria for temporomandibular disorders: Axis II para o português. J Bras Clín Odontol Integr. 2004;8(43):51-61.

21. Fonseca DM, Bonfante G, Valle AL, Freitas SFT. Diagnóstico pela anamnese da disfunção craniomandibular. Rev Gaúcha de Odontol. 1994;42(1):23-8

22. Iunes DH, Castro FA, Salgado HS, Moura IC, Oliveira AS, Bevilaqua-Grossi D. Confiabilidade intra e interexaminadores e repetibilidade da avaliação postural pela fotogrametria. Rev Bras Fisioter. 2005;9(3):327-34.

23. Marton N, Martins NS. Estudo comparativo das radiografias cefalométricas laterais em posição convencional e em postura natural da cabeça (postura preconizada por Rocabado) uma análise dos arcos dentários. Ortodontia. 2001;34(2):73-9.

24. Rocabado MS. Relaciones biomecánicas de las regiones craneales, cervicales e hióideas. Ortodoncia. 1994;58(115):51-6.
25. Deltoff MN. Diagnostic imaging of the crânio-cervical region. In: Vernon $H$. The cranio-cervical syndrome. Mechanisms, assessment and treatment. London: Butterworth Heinemann; 2001. p. 49-87.

26. Kendall FP, McCreary EK, Provance EG. Músculos: provas e funções. $5^{\mathrm{a}} \mathrm{ed}$. São Paulo: Manole; 1995.

27. Braun BL. Postural differences between asymptomatic men and women and craniofacial pain patients. Arch Phys Med Rehabil. 1991;72(9):653-6.

28. Hackney J, Bade D, Clawson A. Relationship between forward head posture and diagnosed internal derangement of the temporomandibular joint. J Orofac Pain. 1993;7(4):386-90.

29. Zonnenberg AJ, Van Maanen CJ, Oostendorp RA, Elvers JW. Body posture photographs as a diagnostic aid for musculoskeletal disorders related to temporomandibular disorders (TMD). Cranio. 1996;14(3):225-32.

30. Rocabado MS, Tapia V. Estúdio radiográfico de relación craneocervical em pacientes bajo tratamiento ortodóncio y su incidência com sintomas referidos. Ortodoncia. 1994;58(115):59-63.

31. Mateus RA. Estudo da posição natural da cabeça em relação as disfunções temporomandibulares [tese]. Piracicaba (SP): Faculdade de Odontologia de Piracicaba- UNICAMP; 2005.

32. Kritsineli M, Shim YS. Malocclusion body posture and temporomandibular disorder in children with primary and mixed dentition. J Clin Pediatr Dent. 1992;16(2):86-93.

33. Bevilaqua-Grossi D, Chaves TC, Oliveira AS. Cervical spine signs and symptoms: perpetuating rather than predisposing factors for temporomandibular disorders in womem. J Appl Oral Sci. 2007;15(4): 259-64. 